Journal of Animal and Veterinary Advances 9 (22): 2784-2787, 2010

ISSN: $1680-5593$

(C) Medwell Journals, 2010

\title{
Polymorphism Identification and Association with Milk Production Traits of KLF3 Gene in a Chinese Holstein Population
}

\author{
${ }^{1}$ Zongjun Yin, ${ }^{2}$ Gui Mei, ${ }^{2}$ Yang Liu, ${ }^{2}$ Xiangdong Ding and ${ }^{2}$ Qin Zhang \\ ${ }^{1}$ College of Animal Science and Technology \\ Anhui Agricultural University, Hefei 230036, P.R. China \\ ${ }^{2}$ Key Laboratory of Animal Genetics and Breeding of the Ministry of Agriculture, \\ College of Animal Science and Technology, \\ China Agricultural University, Beijing 100193, P.R. China
}

\begin{abstract}
Based on QTL fine mapping results on bovine chromosome 6 in the previous studies, KLF3 gene was chosen as a candidate gene to evaluate its effect on milk production traits in a Chinese Holstein population. A SNP (NC_007304:g.13849 G>C) in exon4 of KLF3 gene was demonstrated by directly sequencing of PCR product. Milk production traits including milk yield, fat yield, protein yield, fat percentage and protein percentage of each cow were collected by using 305 days lactation records. The further association analysis of the SNP genotype with milk production traits were conducted in a Chinese Holstein population including 1417 cows. We found that there were a SNP associated significantly with milk yield $(\mathrm{p}=0.022)$ and protein yield $(p=0.033)$. The effect of CC genotype of SNP $\left(\mathrm{NC}_{-} 007304\right.$ :g.13849 $\left.\mathrm{G}>\mathrm{C}\right)$ was significantly higher than other genotype $(\mathrm{p}<0.05)$ in both traits. The study suggested that the KLF3 gene could be used for marker assisted selection program as a molecular marker gene for milk yield, protein yield in Holstein dairy cattle breeding.
\end{abstract}

Key words: Polymorphism, association, KLF3 gene, milk production traits, Chinese Holstein, protein yeild

\section{INTRODUCTION}

In dairy cattle, chromosome 6 (BTA6) is one of the most concerned chromosomes in QTL mapping for milk production traits. Several fine mapping studies have been conducted for BTA6 and provided strong evidence for the existence of a QTL affecting fat or/and protein percentage located near marker BM1 43 (Ron et al., 2001; Olsen et al., 2004; Schnabel et al., 2005). In the former study of a Chinese Holstein population consisting of 26 sire families, we also revealed one or more significant QTLs effects on milk yield, fat yield, protein yield, fat percentage and mapped the QTL for milk yield and protein yield around marker BMS470 which is about $14 \mathrm{cM}$ away from marker BM1 43 with about $4 \mathrm{cM}$ confidence intervals (Chen et al., 2005, 2006).

This region was also reported to harbor one or more QTLs for milk production traits by several investigators (Zhang et al., 1998; Velmala et al., 1999; Harder et al., 2006). In the further fine mapping study, Mei et al. (2009) mapped a QTL for milk production traits in the confidence intervals by increasing the marker density and mapped a interval region surrounded by the markers BMS483 and MNB209; this interval spans about 1.5 Mb (59.41-60.94
$\mathrm{Mb})$. By scanning the genome sequence corresponding to the interval between BMS483 and MNB209 there are 13 known genes: TBC1D1, KLF3, TLR10, TLR1, TLR6, LOC511583, TMEM1 56, KLHL5, WDR19,LO514842, RPL9, LLAS and UGDH gene. KLF3 gene is a member of the Krüppel-Like Factors (KLFs) family of zinc finger proteins which are involved in many biological processes such as cell proliferation, differentiation, apoptosis and neoplastic transformation (Eaton et al., 2008). Research on knock-out mice has showed that KLF3 gene was an important component of transcriptional machinery in eukaryotic cells (Funnell et al., 2007) and transcriptional control of adipogenesis (Sue et al., 2008). KLF3 gene also regulated muscle specific gene expression and synergizes with serum response factoron KLF binding sites (Himeda et al., 2010). In this study, we chose KLF3 gene from the QTL region of fine mapping and investigated the polymorphism of KLF3 gene and evaluate its effect on milk production traits in Chinese Holstein dairy cattle.

\section{MATERIALS AND METHODS}

Animals: Blood samples of 1417 Chinese Holstein cows were collected randomly from eight Chinese Holstein

Corresponding Author: Qin Zhang, College of Animal Science and Technology, China Agricultural University, Beijing 100193, P.R. China 
cattle farms in Beijing, including sire families with 64-288 daughters from each sire. The average 305 days milk yield of those animals was about $8500 \mathrm{~kg}$ and their regular and standard performance testing (Dairy Herd Improvement, DHI) has been recorded since 1999. The individual phenotype for each of five milk production traits (i.e., milk yield, fat yield, protein yield and fat percentage and protein percentage over 305 days) which were obtained from the Beijing Dairy Cattle Center is composed of three records corresponding to different parity. The total number of production records was 2963 and the mean and Standard Deviation (SD) of the five traits are shown in Table 1.

Genotyping and sequencing analysis: Genomic DNA was extracted from blood samples of cows using the phenolchloroform method. Using Primer 5.0 software, five pairs of primers corresponding to five exons and promoter regions were designed according to the genomic sequence of KLF3 gene (GenBank accession no. NC_007304) (Table 2). The PCR was carried out in a total volume of $25 \mu \mathrm{L}$ including $60-80 \mathrm{ng}$ of template DNA, 10 pmol of each primer, $250 \mu \mathrm{M}$ dNTPs, $2.5 \mu \mathrm{L} 10 \times$ PCR buffer (with $\mathrm{MgCl}_{2}$ ) and $1.0 \mathrm{U}$ Taq polymerase (TaKaRa Biotechnology, China).

PCR was performed in a MJ Research PTC-200 Thermal Cycler (BIO-RAD, USA) under the following reaction procedure: initial denaturation at $95^{\circ} \mathrm{C}$ for $5 \mathrm{~min}$ followed by 35 cycles of denaturation at $95^{\circ} \mathrm{C}$ for $40 \mathrm{sec}$, annealing at $\mathrm{X}^{\circ} \mathrm{C}$ for $40 \mathrm{sec}$ ( $\mathrm{X}$ was shown in Table 2 ) and extension at $72^{\circ} \mathrm{C}$ for $45 \mathrm{sec}$ with a final extension step at $72^{\circ} \mathrm{C}$ for $5 \mathrm{~min}$.

To identify the mutation site, the PCR products were purified using DNA Gel Extraction Kit (Tiangen Biotechnology, China) and then sequenced on the ABI 377 DNA Sequencer. Both forward and reverse

Table 1: Means and standard deviation of five milk production traits

\begin{tabular}{|c|c|c|c|}
\hline \multicolumn{2}{|l|}{ Traits } & \multicolumn{2}{|c|}{ Mean \pm SD } \\
\hline \multicolumn{2}{|c|}{ Milk y ield (kg) } & \multicolumn{2}{|c|}{$8569.16 \pm 1638.46$} \\
\hline \multicolumn{2}{|l|}{ Fat yield (kg) } & \multicolumn{2}{|c|}{$342.54 \pm 75.68$} \\
\hline \multicolumn{2}{|c|}{ Protein yield (kg) } & \multicolumn{2}{|c|}{$284.34 \pm 54.62$} \\
\hline \multicolumn{2}{|l|}{ Fat $(\%)$} & \multicolumn{2}{|c|}{$3.94 \pm 0.49$} \\
\hline \multicolumn{2}{|l|}{ Protein $(\%)$} & \multicolumn{2}{|c|}{$3.29 \pm 0.23$} \\
\hline \multicolumn{4}{|c|}{ Table 2: Primers used for SNP identification of bovine KLF3 gene } \\
\hline Fragments & Primers sequence $\left(5^{\prime} \sim 3^{\prime}\right)$ & $\begin{array}{l}\text { Product } \\
\text { size (bp) }\end{array}$ & $\begin{array}{c}\text { Anmealing } \\
\left(\mathrm{X}^{\circ} \mathrm{C}\right)\end{array}$ \\
\hline \multirow[t]{2}{*}{ KLF3-Exon1 } & AGAGGAAGGACCAGAGAAGC & & \\
\hline & GCCTATCAAATGCCTGTCAG & 308 & 59.0 \\
\hline \multirow[t]{2}{*}{ KLF3-Exon2 } & ACTGAATGTGCCTTGTTGTG & & \\
\hline & CAGACTCCCTGGTAGTGAAG & 398 & 59.5 \\
\hline \multirow[t]{2}{*}{ KLF3-Exon3 } & TGCCAAAGGTAGATACTCAC & & \\
\hline & TTCCATTCCAGTTCTGAGAT & 257 & 60.0 \\
\hline \multirow[t]{2}{*}{ KLF3-Exon4 } & GCCAGTGTTGTTAATGCTT & & \\
\hline & TGGTAACTTTCAAGATGCCT & 329 & 58.8 \\
\hline \multirow[t]{2}{*}{ KLF3-Exon5 } & GCTGAGCCTTACATATACGC & & \\
\hline & GGGAAGGAGGATAGAGAGAG & 398 & 60.5 \\
\hline
\end{tabular}

primers were used to sequencing. Have been identified the SNP all samples for SNP genotyping by direct sequencing of PCR products.

Association analysis: Association analysis between genotypes of the SNP and milk production traits were tested by using in SAS9.1.3 software based on the animal models. Pedigrees of animals detected in the present study were traced back to three generations to create the numerator relationship matrix. The animal model is as follows:

$$
\mathrm{Y}_{\mathrm{i}}=\text { hys }_{\mathrm{j}}+\mathrm{F}_{\mathrm{k}}+\mathrm{M}_{\mathrm{n}}+\mathrm{G}_{\mathrm{i}}+\mathrm{r}_{\mathrm{i}}+\mathrm{p}_{\mathrm{i}}+\mathrm{e}_{\mathrm{i}}
$$

Where:

$Y_{i}=$ The vector of the phenotypic value for each trait of cow i

hys $_{\mathrm{j}}=$ The vector of the herd-year-season effect

$\mathrm{F}_{\mathrm{k}}=$ The vector of the parity number effect

$M_{n}=$ The vector of the month effect

$\mathrm{G}_{\mathrm{i}}=$ The vector of the fixed effect corresponding to the genotype of SNP (NC_007304:g.13849 G>C)

$\mathrm{r}_{\mathrm{i}}=$ The vector of the random polygenic component account for known pedigree relationships (Animal model; Lynch and Walsh, 1998) including ungenotyped individuals whose phenotypes was ignored

$\mathrm{P}_{\mathrm{i}} \quad=$ The permanent environmental effect component

$\mathrm{e}_{\mathrm{i}}=$ The random residuals

\section{RESULTS AND DISCUSSION}

Identification of polymorphism: Through the five pairs of primers, we successfully amplified out all the expected fragments for five exons and partial promoter region of KLF3 gene. After directly sequencing for PCR fragment, one Single-Nucleotide Polymorphism (SNP) was identified in exon4 (Fig. 1).

By comparing the sequences of two types of homozygote on SNP, we found that the SNP showed a nucleotide transition from $\mathrm{G}$ to $\mathrm{C}$ at $13849 \mathrm{bp}$ of the gene, called SNP (NC_007304:g.13849 G>C). After peptidebinding region predicted by DNAMAN software (version 5.2.2), the SNP in the peptide-binding region of KLF3 gene is synonymous substitution. A total number of 1417 DNA samples from Holstein cow population were genotyped and allele frequencies of the SNP are shown in Table 3. The frequency of $\mathrm{C}$ allele (0.83) was higher than that for $\mathrm{G}$ (0.17) and is obviously dominant allele in Chinese Holstein population.

Association analyses: Based on statistical analysis, supporting relationship between different genotypes of SNP and milk production traits is found. Comparisons 

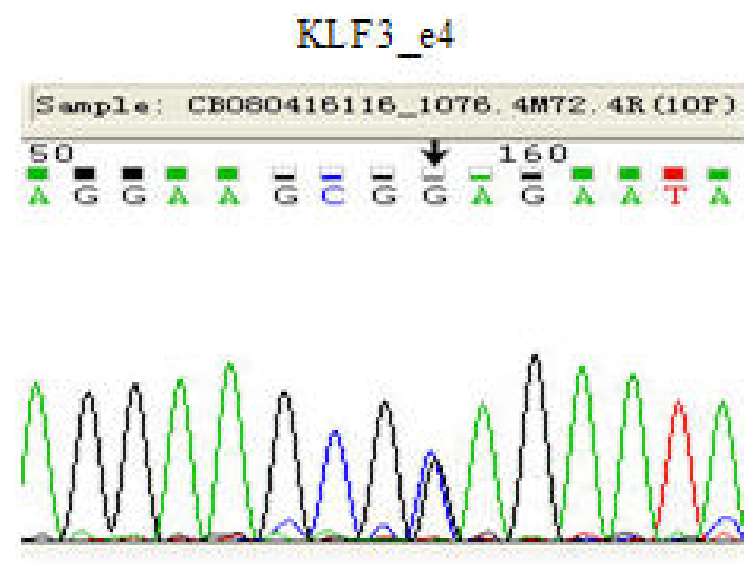

Fig. 1: Sequencing map for SNP (NC_007304: g.13849 $\mathrm{G}>\mathrm{C}$ ) of KLF3 gene and the SNP is indicated by black arrow

Table 3: Genotype and allelic frequencies of SNP (NC_007304:g.13849 $\mathrm{G}>\mathrm{C}$ )

\begin{tabular}{|c|c|c|c|c|c|}
\hline \multirow[b]{2}{*}{ Number } & \multicolumn{3}{|c|}{ Genotype frequency } & \multicolumn{2}{|c|}{ Allele frequency } \\
\hline & GG & $\mathrm{GC}$ & $\mathrm{CC}$ & $\mathrm{G}$ & $\mathrm{C}$ \\
\hline 1417 & $\begin{array}{l}0.03 \\
(n=43)\end{array}$ & $\begin{array}{l}0.28 \\
(n=397)\end{array}$ & $\begin{array}{l}0.69 \\
(\mathrm{n}=\end{array}$ & 977) & 0.83 \\
\hline \multirow[t]{2}{*}{ Table 4: } & \multicolumn{4}{|c|}{ (NC_007304:g.13849 G>C) on the milk production traits } & SNP \\
\hline & \multicolumn{5}{|c|}{$\begin{array}{l}\text { Multiple comparison }{ }^{2} \\
\text { (Least square mean } \pm \text { SE) }\end{array}$} \\
\hline Traits $^{1}$ & GG & $\mathrm{GC}$ & & $\mathrm{CC}$ & $\mathrm{p}$ value \\
\hline MY & $439.53 \pm 160.35^{a}$ & $268.20 \pm$ & $98.63^{b}$ & $822.61 \pm 758.35^{\mathrm{a}}$ & $0.022^{*}$ \\
\hline FY & $-9.40 \pm 3.74$ & $-12.15 \pm$ & & $-2.71 \pm 5.06$ & 0.568 \\
\hline PY & $12.63 \pm 4.39^{\mathrm{a}}$ & $6.85 \pm$ & $45^{b}$ & $17.78 \pm 20.90^{\mathrm{a}}$ & $0.033^{*}$ \\
\hline FP & $-0.06 \pm 0.02$ & $-0.09 \pm$ & & $-0.07 \pm 0.02$ & 0.814 \\
\hline $\mathrm{PP}$ & $-0.02 \pm 0.01$ & $-0.01 \pm$ & & $-0.01 \pm 0.04$ & 0.705 \\
\hline
\end{tabular}

${ }^{1}$ MY, Milk Yield; FY, Fat Yield; PY, Protein Yield; FP, Fat Percentage; PP, Protein Percentage; ${ }^{2}$ Comparison between different genotypic values of MY, FY, PY, FP and PP for SNP locus; * $\mathrm{p}<0.05$; ${ }^{\text {a, b }}$ Statistically different of least square means $(p<0.05)$

between the least squares means of the phenotypes evaluated and their respective standard errors for the genotypes of the SNP are shown in Table 4. There were significant associations with milk yield $(p=0.022)$ and protein yield $(\mathrm{p}=0.033)$. Both milk yield and protein yield of cows with GC genotype is lower than those with genotype $\mathrm{CC}$ in the Holstein populations.

QTL fine mapping results will facilitate the cloning of candidate genes underlying the QTLs for production traits, several strong candidate genes with potential effect on milk production traits were identified from the mapped region by the same mapping method including OPN gene and the ABCG2 gene (Schnabel et al., 2005; Cohen-Zinder et al., 2005). KLF3 gene is negative regulator of adipogenesis (Sue et al., 2008) and involved in haematopoietic differentiation (Turner and Crossley, 1999). Although, the annotated functions of the KLF3 gene do not show direct relation to milk production traits, KLF3 gene is participated in the important cellular development and may have similar impact on the mammary cells. In the study, the SNP (NC_007304:g.13849 $\mathrm{G}>\mathrm{C}$ ) of KLF3 gene was found to be significantly associated with MY and PY among the five milk production traits.

This may be because that KLF3 gene is ascribed to insufficient exploitation of functions or the polymorphisms within the KLF3 may relate to the QTL effects in this interval region. In addition, the association between the SNP and milk production traits shown in this study also suggests that they are in linkage or are in strong linkage disequilibrium with the polymorphisms responsible for the phenotypic alterations in the $4 \mathrm{Mb}$ QTL regions.

Furthermore, the SNP (NC_007304:g.13849 G>C) is located in coding sequence of the KLF3.gene but it is synonymous substitution. Capon et al. (2004) reported that synonymous SNPs also can affect protein expression by alteration or increase in the stability of the mRNA.

Kimchi-Sarfaty et al. (2007) has also revealed that a silent polymorphism changes substrate specificity. Therefore, the association result indicated that the SNP also may simply be used as a genetic marker linking to QTL with effects on milk yield and protein yield. Further studies on the relationship between other candidate genes from the QTL region in BAT6 and milk production traits are currently in progress.

\section{CONCLUSION}

In the results, the association analysis revealed an SNP in exon4 of KLF3 gene which showed significant associations with two milk production traits in Chinese Holstein.

Based on the resultof the pervious QTL mapping and this study, we suggested that KLF3 gene could be a potential genetic marker for marker assist selection in Holstein dairy cattle breeding.

\section{ACKNOWLEDGEMENTS}

The researchers thank Beijing Dairy Cattle Center for providing us the DHI data and the blood samples. This research was supported by the National Key Basic Research Program of China (No. 2006CB102104) and the Project of Anhui Scientific Technology Plan (Grant No. 08010301079). 


\section{REFERENCES}

Capon, F., M.H. Allen, M. Ameen, A.D. Burden, D. Tillman, J.N. Barkerand and R.C. Trembath, 2004. A synonymous SNP of the corneodesmosin gene leads to increased mRNA stability and demonstrates association with psoriasis across diverse ethnic groups. Human Mol. Genet., 13: 2361-2368.

Chen, H.Y., Q. Zhang, C.K. Wang, J. Shu and G. Mei et al., 2005. Mapping QTLs on BTA6 affecting milk production traits in a Chinese holstein population. Chinese Sci. Bull., 50: 1737-1742.

Chen, H.Y., Q. Zhang, C.C. Yin, C.K. Wang, W.J. Gong and G. Mei, 2006. Detection of quantitative trait loci affecting milk production traits on bovine chromosome 6 in a chinese holstein population by the daughter design. J. Dairy Sci., 89: 782-790.

Cohen-Zinder, M., E. Seroussi, D.M. Larkin, J.J. Loor and A. Everts-vander Wind et al., 2005. Identification of a missense mutation in the bovine $\mathrm{ABCG} 2$ gene with a major effect on the QTL on chromosome 6 affecting milk yield and composition in Holstein cattle. Genome Res., 15: 936-944.

Eaton, S.A., A.P. Funnell, N. Sue, H. Nicholas, R.C. Pearson and M. Crossley, 2008. A network of Kruppel-like factors (KIfs). KIf8 is repressed by KIf3 and activated by Kifl in vivo. J. Biol. Chem., 283: 26937-26947.

Funnell, A.P., C.A. Maloney, L.J. Thompson, J. Keys, M. Tallack, A.C. Perkins and M. Crossley, 2007. Erythroid kruppel-like factor directly activates the basic Kruppel-like factor gene in erythroid cells. Mol. Cell. Biol., 27: 2777-2790.

Harder, B., J. Bennewitz, N. Reinsch, G. Thaller and H. Thomsen et al., 2006. Mapping of quantitative trait loci for lactation persistency traits in German holstein dairy cattle. J. Anim. Breed. Genet, 123: 89-96.

Himeda, C.L., J.A. Ranish, R.C. Pearson, M. Crossley and S.D. Hauschka, 2010. KLF3 regulates musclespecific gene expression and synergizes with serum response factor on KLF binding sites. Mol. Cell. Biol., 30: 3430-3443.
Kimchi-Sarfaty, C., J.M. Oh, I.W. Kim, Z.E. Sauna, A.M. Calcagno, S.V. Ambudkar and M.M. Gottesman, 2007. A silent polymorphism in the MDR1 gene changes substrate specificity. Sciences, 315: 525-528.

Lynch, M. and B. Walsh, 1998. Genetics and Analysis of Quantitative Traits. Sinauer Associates Inc., Sunderland.

Mei, G., C.C. Yin, X.D. Ding and Q. Zhang, 2009. Fine mapping quantitative trait loci affecting milk production traits on bovine chromosome 6 in a Chinese holstein population. J. Genet. Genomics, 36: 1-8.

Olsen, H.G., S. Lien, M. Svendsen, H. Nilsen, A. Roseth, M.A. Opsal and T.H.E. Meuwissen, 2004. Fine mapping of milk production QTL on BTA6 by combined linkage and linkage Disequilibrium analysis. J. Dairy Sci., 87: 690-698.

Ron, M., D. Kliger, E. Feldmesser, E. Seroussi, E. Ezra and J.I. Weller, 2001. Multiple quantitative trait locus analysis of bovine chromosome 6 in the Israeli Holstein population by a daughter design. Genetics, 159: 727-735.

Schnabel, R.D., J.J. Kim, M.S. Ashwell, T.S. Sonstegard, C.P. van Tassell, E.E. Connor and J.F. Taylor, 2005. Fine-mapping milk production quantitative trait loci on BTA6: Analysis of the bovine osteopontin gene. Proc. Nat. Acad. Sci. USA., 102: 6896-6901.

Sue, N., B.H. Jack, S.A. Eaton, R.C. Pearson and A.P. Funnell et al., 2008. Targeted distuption of the basic Kruppel-like factor gene (KIf3) reveals a role in adipogenesis. Mol. Cell. Biol., 28: 3967-3978.

Turner, J. and M. Crossley, 1999. Basic Krupple-like factor functions within a network of interacting haematopoietic transcription factors. Int. J. Biochem. Cell Biol., 31: 1169-1174.

Velmala, R.J., H.J. Vilkki, K.T. EIo, D.J. de Koning and A.V. Maki-Tanila, 1999. A search for quantitative trait loci for milk production traits on chromosome 6 in Finnish Ayrshir cattle. Anim. Genet., 30: 136-143.

Zhang, Q., D. Boichard, I. Hoschele, C. Ernst and A. Eggen et al., 1998. Mapping quantitative trait loci for milk production and health of dairy cattle in a large outbreed pedigree. Genetics, 149: 1959-1973. 